\title{
A LINEAR MODEL FOR THE COLLECTION OF INSTITUTIONAL PLASTIC WASTES IN GHANA: A CASE OF THE COUNCIL FOR SCIENTIFIC AND INDUSTRIAL RESEARCH-INSTITUTE OF INDUSTRIAL RESEARCH (CSIR-IIR)
}

\author{
A. B. Yeboah *, S. Odei And E. Anabila \\ (Council for Scientific and Industrial Research (CSIR) - Institute of Industrial Research \\ (IIR), Materials and Manufacturing Division, \\ P.O. Box LG 576, Legon-Accra, Ghana). \\ *Corresponding author's email: boniface.antwi@gmail.com
}

\begin{abstract}
The collection of plastic wastes (p-wastes) in Ghana has received attention in recent years. However, there are persistent disposal of the p-wastes into the environment with associated costs to life on land, sea and in the air. The collection of domestic and industrial p-wastes, contributes to the national recycling rates whilst the intuitional p-wastes lags behind with minimal backing and contributions. For this reason, the study sought to explore the structures required to improve plastic wastes collection at the workplace to enhance recycling and greener jobs. In the pilot study, workers at the CSIR-IIR were interviewed to determine a premier model for the efficient collection of the institutional plastic wastes. The methodology included random administration and retrieval of questionnaires, coding and tallying of survey responses, and the processing of generated data. The research questions bordered on the most generated solid and plastic wastes, the preferred mode of collection and the expected gains to the institution. Qualitatively, plastic wastes were the most generated solid wastes. Purified water sachets formed the bulk of generated p-wastes. Source sorting was favoured over the mixed mode of collecting the solid wastes, which will contribute to income generation and a linear collection model.
\end{abstract}

Keywords: Institutional plastic wastes, linear model, plastic wastes collection, source sorting of plastic wastes, model for plastic wastes collection.

\section{Introduction}

Plastics (or organic polymers) are malleable and easy to mould into different shapes and sizes and synthesised from petrochemicals (e.g. polyethylene, Styrofoam, Teflon etc.) or obtained naturally (e.g. cellulose, wood sap etc.). Chemically altered natural plastics such as rubbers, cellulosic plastics, and casein form the semisynthetic class of plastics. A mechanical description of plastics groups them into thermoplastics (disorganized low crosslinking), thermosets (disorganised high crosslinking) and elastomers (organised low crosslinking). Examples include polyethylene, epoxies and silicones respectively. The utilisation of plastics in diverse applications have provided affordable, lightweight, and durable substitutions for glass, wood and metal counterparts whilst conserving the forest and mineral reserves. However, the predominantly 
utilised petrochemical plastics are not biodegradable (Urbanek et al., 2018) which makes them persistent in the environment after single use. Hence the reduction, reuse and recycling of plastic wastes have been promoted to save the environment and keep the life of the plastic in a circular economy loop.

The usage of plastic wastes ( $p$-wastes) in secondary applications such as plastic/aggregate composites for pavement blocks and road construction (Adegoke, 2018), bags, and wallets (Tandoh, 2018) have received recent attention in Ghana. These p-wastes are collected by recognised groups, such as the Plastic Waste Collectors Association (PWCA), Plastic Pickers Association (PPA), and Environment-360, who sell or use them in making secondary products. For example, the PWCA collects over 120 metric tonnes of p-wastes in Accra daily,(Ezit, 2016). However, Ghana recycles only $2 \%$ of an annually generated 1.7 million tonnes of p-waste (Ibrahim, 2019), with a per capita p-waste generation between $0.016-0.035 \mathrm{~kg} /$ person/day, (Kortei \& Quansah, 2016). This indicates that, $98 \%$ of the p-wastes leak into the environment every year, which may increase with increasing markets for plastic products in Ghana (Mohinani, 2018). These unrecycled p-wastes remain in the environment as air, land and water pollutants, (Abota, 2012).

The global drive to improve on the worldwide 9\% recycling rate since 1950 (D'Ambrieres, 2019) has attracted programmes and efforts by countries to reduce the plastic waste burden on society and the environment. For instance, the proposed sustainable and zero waste models in India with underlying concept of maximum resource recovery in a greener way, (Pankaj, 2015) contributed to the recycling of a fourth of its annual 15 million tonnes plastic wastes generation. Similarly, The reverse logistics model (Sury- ana et al., 2019) in Indonesia enhanced a $24 \%$ recycling rate of Jakarta's generated plastic wastes, (Putri et al., 2018). On the other hand, a weak institutional structure and capacity, contributed to the unsuccessful implementation of regulatory framework for the collection and recycling of plastic and other solid wastes in Kenya (Haregu et al., 2017).

In the Ghanaian approach, a study on the framework for the formal collection of purified water plastic wastes outlined the producer and state recovery models as the two key scenarios that will effectively enhance the management of the plastic waste, (Quartey et al., 2015). Even though it emphasised on only one type of plastic wastes (pure water sachet), its gradual implementation has resulted in the establishment of small buy back companies and the intercompany (producer) networks such as the Ghana Recycling Initiative by Private Enterprises (GRIPE) whose activities buy back plastic wastes, promote research and supports government policies (GRIPE, 2017). Similarly, the Government of Ghana under the leadership of The President, His Excellency Nana Addo Danquah Akufo-Addo has established the regulatory frameworks for plastic waste collection in Ghana through the Ministry of Environment Science, Technology and Innovation (MESTI). This include, becoming the first African country to collaborate with the Global Plastic Action Partnership (GPAP) hosted at the World Economic Forum (WEF), (Cann, 2019) which aims at eradicating plastic wastes and pollutions worldwide. Additionally, the launch of the Ghana National Plastic Action Partnership (GNPAP) to support the implementation of the National Plastic Management Policy (NPMP) (Graphiconline, 2019), towards a sustainable plastic circular economy and environmental protection. Furthermore, the Ghana Innovation and Research Commercialisation (GIRC) Centre, (Setsoafia, 
2019) has been setup by the Government to transform innovations and research into industries. These interventions set the foundation for a plastic free environment in Ghana.

Recommendations on the producer and state recovery models indicates a missing link between responsibility shares between the informal collectors, mostly communities and institutions and the formal sectors being producers and government in the plastic waste management chain.

The informal collection involves an uncoordinated branched approach (Fig. 1) that has the generated p-wastes mixed with other solid wastes (such as, paper, metal, wood, glass and food) or sorted and saved by some individuals and industries. The waste collectors pick the mixed and sorted wastes whilst the uncollected wastes are buried or burnt by the generators (Owusu-Sekyere et al., 2013). In some cases, the sorted and saved p-wastes are uncollected, whilst they pill-up. Upon collection, the plastic wastes may end up on landfill sites or recycled by p-wastes companies. Craft men/ women purchase some of the collected plastic wastes for secondary use in innovations such as, p-waste/aggregate composites, bags, beds, and so on (Tandoh, 2018; Adegoke, 2018). The buried $\mathrm{p}$-wastes which are exposed during rainfall or construction works further contribute to the pollution of the environment (Abota, 2012). Even though some plastic wastes are recycled in the informal sector, a well-coordinated system will maximise collection and investments.

Therefore, this work proposes an easy to coordinate linear model for the effective collection of the $\mathrm{p}$-wastes through a qualitative study of consumer preferences. The model will bridge the informal and formal collection sector gap whilst promoting optimum plastic waste recycling and environmental cleanliness.

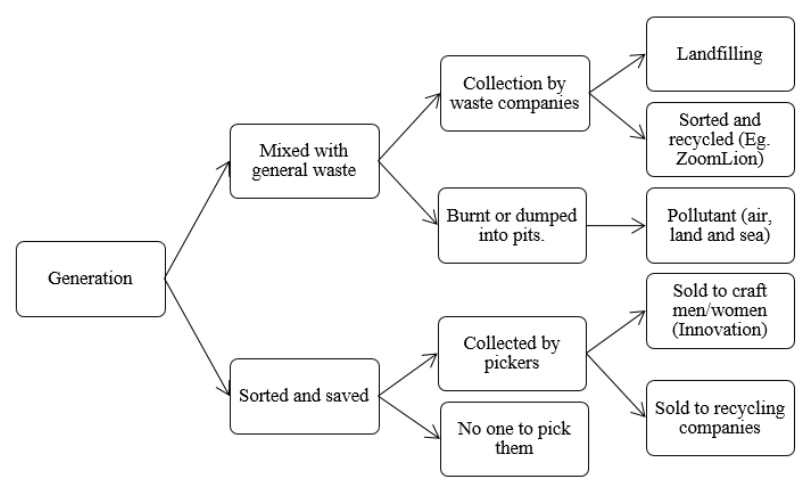

Fig. 1: Informal plastic waste collection practices in Ghana.

\section{Purpose of study}

The purpose of this study was to determine the consumer viewpoint through a qualitative study of workers at the Council for Scientific and Industrial Research-Institute of Industrial Research (CSIR-IIR) on p-waste collection at the work place. Survey responses contributed to a proposed linear model for the collection of the p-wastes. Thus the linear model will be the foremost scientific bases for 'at source solid waste segregation' at the workplace in Ghana. 


\section{Research questions}

\section{Experimental}

The study was directed by the following questions:

$(\alpha)$ What plastic waste forms the most abundant solid waste in the Institute?

$(\beta)$ What is the preferred mode and vessel for collecting the waste?

$(\chi)$ What benefits does the Institute derive from the effective collection of the waste?

The study area was the CSIR-IIR, East-Legon, Accra. The diverse social background of the staff provided a bases for choosing the Institute. Data generated from the survey represent the varied social spectrum at the CSIR-IIR.

\section{Study design}

The exploratory research design was adopted which was carried out by a qualitative data collection method. Administered questionnaires were tallied to generate graphs for interpretations.

\section{Sampling and sample size}

The random sampling of respondents was carried out. Sample size was calculated from the formula described by Yamane (1973) and (Ajay \& Micah, 2014). The formula combines the population size and the margin of error to arrive at the minimum number of samples that could be selected. The sample size was estimated as follows:

$n=\frac{N}{1+N(\varepsilon)^{2}}=\frac{107}{1+107(0.10)^{2}}=$

Where: $\mathrm{n}=$ the minimum sample size; $\mathrm{N}=$ total population $=107 ;{ }^{\varepsilon}=$ margin of error $(10 \%)$

Therefore, the minimum sample size covered in the study was 51 respondents.

\section{Data collection and analysis}

A simple random sampling was carried out in 10 working days by the administration of 65 questionnaires to staff of CSIR-IIR. The questionnaire recovery rate was $78 \%$, which represented 51 pieces of the distributed forms. The descriptive analysis of data was employed in the interpretation of collected data. Questionnaires were voluntarily completed by staff during lunch break. The questions were carefully explained to staff who could not read and write. The forms were unmarked to ensure confidentiality of respondents.

\section{The instrument}

The Instrument covered demographic information and 19 statements. The statements were organised to answer the three main research questions on the type of $\mathrm{p}$-waste that formed the most abundant solid waste at the CSIR-IIR, the preferred mode (mixed or sorted) and vessel for collection, and the potential derived benefits for efficiently collecting the waste. Statement on the most generated p-waste sought to identify the main p-waste generated by staff of the Institute, the generation frequency and potential economic value. The statements on means of collection intended to identify the perception of respondents on pre-dumping segregation of the wastes, the dedication of waste bins for the separation and preferred aesthetics of the waste bins. Finally, yet importantly, the derived benefits gathered information on the viewpoint of respondents on potential returns that will be gained by the CSIR-IIR during implementation of the study findings.

\section{Data analyses}

Data collected were manually compiled using Microsoft Excel and subsequently exported onto the Statistical Package for the Social Sciences (SPSS) version 18 platform. Frequencies and calculated percentages were recorded in tables and grouped under the three main research questions. 


\section{Results and discussion}

In the study, $70.6 \%$ (36) respondents were males and 29.4\% (15) females; this closely corresponds to the Institutional staffing of $75 \%$ (80) males and $35 \%$ (26) females. The age of respondents fell within the legal age limit for a working adult in Ghana, i.e. between 15 and 60 years, (Ghana Legal, 2018; Parliament of Ghana, 1998). Most of the respondents aged between 46 and 60 years old (54.9\%), with the least number of respondents between 18 and 30 years $(3.9 \%)$. Also, most of the respondents $(93.8 \%)$ exhibited literacy at different stages of the formal education ladder a breakdown shows that, $85.7 \%$ and $6.1 \%$ terminated their education at the tertiary and basic respectively. Responses were sought from the eight Divisions of the Institute. These were the Metrology (6.0\%), Industrial Processes Research $(8.0 \%)$, Materials and Manufacturing (12.0\%), Human Resource and Administration (22.0\%), Engineering Design and Prototype (20.0\%), Finance and Accounting (14.0\%), Business and Information Services $(2.0 \%)$ and Energy Technology (14.0\%). Canteen and food vendors, $(2.0 \%)$ were sampled as well.

What plastic waste forms the most abundant solid waste in the Institute?

Three types of solid wastes were theoretically generated in the Institute, which were plastics, organics and metals (Table 1). Of these three, plastics $(66.6 \%)$, were the most generated followed by organic (28.9\%) and metallic (4.4\%) wastes. This result differed from the theoretical trends in the type and amount of solid wastes generated in other workplaces and municipalities in Ghana, (Owusu-Sekyere et al., 2013). Additionally, the qualitative amount of p-wastes generated in the Institute was more than two-folds of the organics, and 10-folds of the metallics which is consistent with literature (Quartey et al., 2015). This situation means that an improved collection of the p-wastes will result in the provision of a readily available raw material for plastic recycling which will be beneficial to industrial innovations, as well as reduction in the amount of solid wastes dumped on landfills. In addition, the collection of the p-wastes will consequently make readily available organic and metallic wastes for secondary applications such as composting (Adekunle et al., 2011), critical metal recovery (Arda et al., 2018), etc.

TABLE 1

\begin{tabular}{ccc}
\multicolumn{3}{c}{ Types of solid waste generated and their percentages } \\
\hline Type of solid & & Percentage \\
waste generated & Frequency & $(\%)$ \\
\hline Plastic & 30 & 58.8 \\
Organic & 13 & 25.5 \\
Metallic & 2 & 3.9 \\
No Response & 6 & 11.8 \\
Total & 51 & 100.0 \\
\hline
\end{tabular}

Staff responses show that, sachet water plastics were the predominantly generated $\mathrm{p}$-wastes in the Institute compared to the polythene bags and plastic food wrappers, which corresponds to the national perception on the most generated plastic wastes in Ghana, (Ampofo, 2013). The abundance of pure-water sachets (made from a blend of low and high density polyethylene (LDPE/ HDPE)) indicates a readily available raw material of $p$-waste that can be utilised in the manufacture of second generation plastic products. Further investigations showed that, waste pure-water sachets were disposed off a common practice among $78.5 \%$ respondents. This demonstrates a consistency in the generation of the large quantities of p-waste for recycling and industrial innovations. An average of five pure-water sachets was disposed off daily by respondents, (Table 2). 
TABLE 2

\begin{tabular}{lllllll}
\multicolumn{5}{c}{ Summary of waste plastics thrown } & away by respondents daily & \\
\hline & $\mathrm{N}$ & Min & Max & Mean & Std. Deviation \\
\hline $\begin{array}{l}\text { How many of these waste plastics do you } \\
\text { throw away in a day? }\end{array}$ & 51 & 0 & 35 & 5.38 & 6.537 \\
\hline
\end{tabular}

Calculations from the mean value (5), shows that, 255 pieces of the waste plastics were thrown away by the 51 respondents in a day which multiplies to 1275 and 5100 pieces in 5 and 20 working days respectively. Therefore, the pure water sachet waste plastic could be accessed daily for economic gains (Temitope et al., 2015).

Additionally, respondent's perspectives on how much $1 \mathrm{~kg}$ of the $\mathrm{p}$-wastes should cost showed that, $43.7 \%$ of staff preferred to sell $1 \mathrm{~kg}$ of the segregated p-wastes for $\mathrm{GH} \phi$ 5.00 rather than selling the same weight for GHф $10.00(\$ 2.00)$ or more. Similarly, most respondents $(66.7 \%)$ charge a fee of GHф 5.00 (\$1.00) for the collection of their p-wastes. This indicates that an amount of GHф 5.00 (\$ 1.00 ) is an acceptable amount that will charge for both sale and collection of $1 \mathrm{~kg}$ of the p-wastes which correspondingly incentivizes the segregation and collection process.

What is the preferred mode and vessel for collecting the waste?

Further investigations into the collection of the p-wastes showed that, overwhelming majority of respondents (94.2\%) favoured the separation of the p-wastes from other solid wastes at source compared to $5.8 \%$ of respondents who opted for a mixed collection. The findings agrees with the Environmental Protection Agency of Ghana (EPA) pilot programme on 'at source waste segregation' in Accra, (Hayfron-Acquah et al., 2013). In addition, allotting waste bins for collecting p-wastes was favoured by the respondents $(98.0 \%)$, as well; The respondents preferred the use of cylindrical blue waste bins compared to other combinations of colours and shapes, (Table 3 ), which is contrasting the current practice of collecting solid wastes in squared shaped dustbins or black or grey cylindrical dustbins (Hayfron-Acquah et al., 2013). It is anticipated that, the colour and shape preferences of respondents for the specialised $\mathrm{p}$-waste bins will enhance the collection process, since individuals will easily relate to the colour, shape and the function. Therefore, the provision of specialised bins will improve the collection and marketing of the p-wastes resource. This is consistent with the recovery model for sachet water, which emphasises on the extended producer responsibility through a reverse logistics network that is mostly dependent on source sorting in designated waste bins (Quartey et al., 2015). 
TABLE 3

Cross-tabulation of preferred colour and shape of the specialized waste bin for plastics

\begin{tabular}{|c|c|c|c|c|c|c|}
\hline & & \multicolumn{3}{|c|}{ Shape of Specialized Waste Bin for Plastics } & \multirow{2}{*}{ Total } & \multirow{2}{*}{ Percentage (\%) } \\
\hline & & Cylinder & Pyramid & Cube & & \\
\hline \multirow{5}{*}{$\begin{array}{l}\text { Colour of } \\
\text { Special } \\
\text { Waste Bin } \\
\text { for Plastics }\end{array}$} & Red & 7 & 4 & 0 & 11 & 21.6 \\
\hline & Blue & 13 & 5 & 0 & 18 & 35.3 \\
\hline & Ash & 3 & 2 & 0 & 5 & 9.7 \\
\hline & Green & 11 & 1 & 2 & 14 & 27.5 \\
\hline & Black & 3 & 0 & 0 & 3 & 5.9 \\
\hline & Total & 37 & 12 & 2 & 51 & 100 \\
\hline \multicolumn{2}{|c|}{ Percentage (\%) } & 72.6 & 23.5 & 3.9 & 100 & \\
\hline
\end{tabular}

To ensure compliance on waste segregation, most respondents (86.3\%) opted for the education of individuals on the benefits of separating waste at source instead of imposing a fine ( $13.7 \%$ respondents). This finding backs literature which emphasises on public awareness in the plastic waste management process (Ampofo, 2013).

What benefits does the Institute derive from the effective collection of the waste?

Generally, the collection, sale and recycling of plastic wastes contribute to the circular economy concept whilst protecting the environment (Owusu, 2010). For this reason, the efficient collection of the p-waste at CSIRIIR is expected to act as a practice that will diversify the income portfolio of the Institute. Hence, $78 \%$ respondents supported the sale of the $\mathrm{p}$-wastes to recycling companies for revenue generation (Owusu-Sekyere et al., 2013). Similarly, the potential reduction in the cost of landfilling wastes was also cited as a prospective gain which corresponds to work by (Geyer et al., 2017).
Proposed linear collection model for p-wastes in Ghana

Following the respondent's perspectives, a linear model (Fig. 2) for the collection of the p-wastes is proposed. This is anticipated to ease the transition from a linear to a circular plastic waste management process with consequential improvement in the national recycling rate of p-wastes (Horvath et al., 2018). Therefore, the linear collection model involves the generation of the p-waste, sorting at source by the use of specialised waste bins, and saving of the sorted wastes for collection. Afterwards, the sorted wastes will be sold to small scale collectors who will subsequently sell or donate to industry for recycling and other innovations. It is anticipated that, an extensive education and the provision of suitable infrastructure will guarantee a successful segregation and collection process. By this linear model, the anomalies and inefficiencies in the sorting and collection process will be easily identified and amended for a comprehensive harnessing of the p-waste resources in Ghana. 


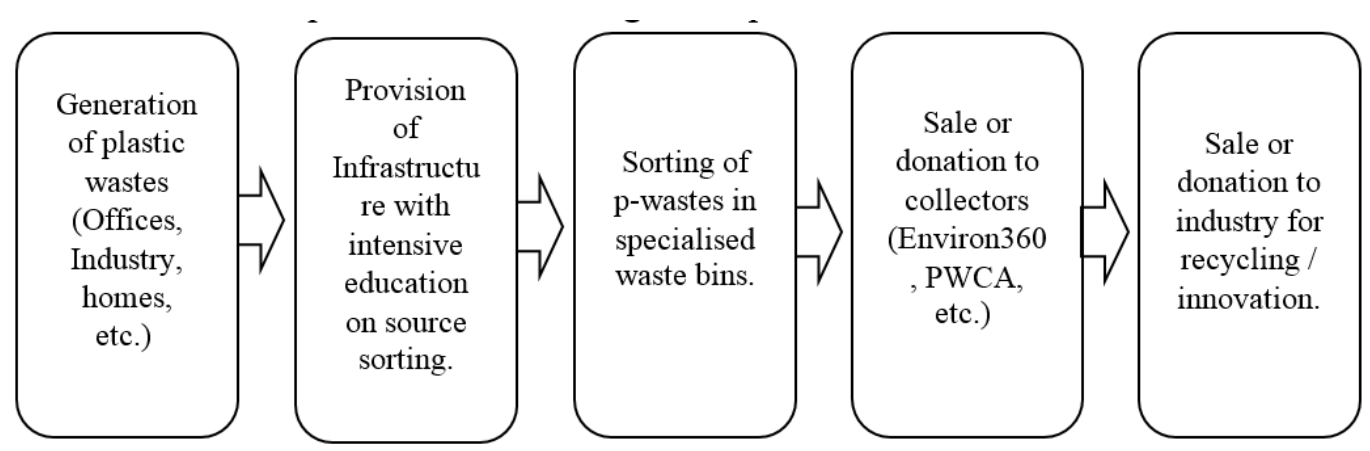

Fig. 2: Proposed linear framework for p-waste collection in Ghana.

\section{Conclusions}

Based on findings from this study, it is concluded that, staff of CSIR-IIR appreciate the extent of p-waste menace in the Institute. The separation of $p$-waste from general solid wastes before dumping was found ideal by respondents. They preferred the use of specialised blue cylindrical waste bins for at source sorting and collection of p-wastes. An amount of GHф 5.00 was favoured for both the sale and purchase of a kilogram p-wastes. The sale of p-wastes for income generation by the Institute was recommended accordingly. Consequently, an effective collection of institutional plastic wastes in Ghana will lie in the sorting of these wastes at source through the provision of specialised waste bins. This will inevitably provide a well-structured system for the removal of p-wastes from the environment and eventually contribute to the clean Ghana campaign and the United Nations' Sustainable Development Goals 12, 14 and 15 on, responsible consumption and production, protection of life below water, and protection of life on land, respectively, (Owusu, 2017).

\section{Acknowledgement}

The authors acknowledge staff and management of the CSIR-IIR for the support and guidance during the study.

\section{References}

АвотА, C. А. (2012) Recycling of plastic wastes in Ghana: A way to reduce environmental problems. Arcda. https://www.theseus.fi/ bitstream/handle/10024/42852/Charles\%20 Abota $\% 20$ final $\% 20$ thesis 1 .pdf? sequence $=1$ : Arcada - Nylands svenska yrkeshögskola.

Adegoke, Y. (2018) How a Ghanaian entrepreneur uses recycled plastic to make cheaper roads and building blocks. [Online]. qz.com/ africa/1263830/how-a-ghanaian-entrepreneur-uses-recycled-plastic-to-make-cheaperroads-and-building-blocks/ [Accessed August 9, 2018. 2018].

Adekunle, I. M., Adekunle, A. A., Akintokun, A. K., Akintokun, P. O. \& Arowolo, T. A. (2011) Recycling of organic wastes through composting for land applications : A Nigerian experience. Waste Management \& Research 29, $582-593$.

Амpofo, S. K. (2013) On the options for the effective management of plastic waste in Ghana [Online].http://fonghana.org/wp-content/ uploads/2013/02/REPORT-ON-MANAGEMENT-OF-PLASTIC-WASTE-IN-GHANA21-328-STASWAPA. . [Accessed July, 2018. 2018].

Arda, I., Rene, E. R., Hullebusch, E. D. V. \& Lens, P. N. L. (2018) Resources, Conservation \& Recycling Electronic waste as a secondary 
source of critical metals : Management and recovery technologies. . Resources, Conservation \& Recycling 135, 296 - 312.

Cann, O. (2019) The Government of Ghana has formally joined the Global Plastic Action Partnership (GPAP), becoming its first African member [Online]. https://www.weforum. org/press/2019/10/ghana-becomes-first-african-nation-to-join-ambitious-partnership-to-end-plastic-pollution/: World Economic Forum. [Accessed 10-01-2020 2020].

D'Ambrieres, W. (2019) Plastics recycling worldwide: current overview and desirable changes. The Journal of Field Actions Science Report, 12 -21 .

Ezit, L. (2016) Plastic waste collectors equipped to enhance operations. [Online]. https:// www.graphic.com.gh/news/general-news/ plastic-waste-collectors-equipped-to-enhance-operations. [Accessed July 8, 2018. 2018].

Geyer, R., Jambeck, J. R. \& Law, K. L. (2017) Production, use, and fate of all plastics ever made. Science Advances 3, 1 - 5.

Ghana Legal. (2018) Civil Service Act - 1993 ( PNDCL 327 ) Section - 71 - Compulsory retirement [Online]. http://www.ilo.org/dyn/natlex/ natlex4.detail?p_lang=en\&p_isn $=33395 \& p$ country $=$ GHA\&p count $=114$. $\quad$ [Accessed July 2, 2018 2018].

GRAPHICONLINE. (2019) Akufo-Addo launches National Plastic Management Policy Oct 1 [Online]. https://www.graphic.com.gh/ news/general-news/ghana-news-akufo-addo-launches-national-plastic-management-policy-oct-1.html. [Accessed 10-012020 2020].

GRIPE. (2017) What is GRIPE [Online]. https:// thegripe.org/what-is-gripe/. [Accessed 1001-2020 2020].

Haregu, T. N., Ziraba, A. K., Aboderin, I., Amugsi, D., Muindi, K. \& Mberu, B. (2017) An assessment of the evolution of Kenya's solid waste management policies and their implementation in Nairobi and Mombasa: analysis of policies and practices. Environment and Urbanization 29, 515 - 532.

Hayfron-Acquah, W., Quaye, S. N. \& Voado, G. C. (2013) Implementation of source waste segregation programme begins. [Online].http://www.ghana.gov.gh/index. $\mathrm{php} / \mathrm{media}-\mathrm{center} / \mathrm{news} / 3702$-implementation-of-source-waste-segregation-programme-begins. [Accessed August, 2018. 2018].

Horvath, B., Mallinguh, E. \& Fogarassy, C. (2018) Designing Business Solutions for Plastic Waste Management to Enhance Circular Transitions in Kenya. Sustainability 10, 1664.

IBRAHIM, R. (2019) Only $2 \%$ of plastic waste generated is recycled [Online]. https://thebftonline.com/2018/headlines/only-2-of-plastic-waste-generated-is-recycled/. [Accessed April 30, 2019 2019].

Kortei, N. K. \& Quansah, L. (2016) Plastic Waste Management in Ghana-A Complete Failure and the Consequences [Online]. https:// www.graphic.com.gh/features/opinion/plastic-waste-management-in-ghana-a-completefailure-and-the-consequences.html [Accessed July 17, 2018. 2018].

Mohinani, G. (2018) Plastics \& Packaging - Ghana Poly Products Ghana Limited Poly Sacks Ghana Limited Poly Tanks Ghana Limited. [Online]. http://www.mohinani.com/content/ docontent/103. [Accessed August 13, 2018 2018].

Owusu-Sekyere, E., Kanton, O. I. \& Yahaya, A.-K. (2013) An Analysis of the Plastic Waste Collection and Wealth Linkages in Ghana. International Journal of Current Research 5 (01), 205 - 209., 5, $205-209$.

Owusu, B. (2017) The Sustainable Development Goals (SDGs) in Ghana. Accra. [Online]. http://gh.one.un.org/content/dam/unct/ghana/ docs/SDGs/UNCT-GH-SDGs-in-Ghana-Av- 
ocacy-Messages-2017. [Accessed August, 2018. 2018].

Owusu, G. (2010) Social effects of poor sanitation and waste management on poor urban communities : a neighborhood - specific study of Sabon Zongo, Accra communities : a neighborhood-specific study of Sabon Zongo, Accra. Urbanism International Research on Placemaking and Urban Sustainabilit, 3, 145 -160 .

Pankaj, V. P. (2015) Sustainable model of plastic waste management. International Journal of ChemTech Research 7, $440-458$.

PARLIAMENT OF GHANA. (1998) The Children ' $s$ Act, 1998 Act 560 [Online]. http://ghanalegal.com/www/category/laws-of-ghana/actsof-the-fourth-republic/childrens-act-1998act-560/. [Accessed July 4, 2018 2018].

Putri, A. R., Fujimori, T. \& Takaoka, M. (2018) Plastic waste management in Jakarta, Indonesia: evaluation of material flow and recycling scheme. Journal of Material Cycles and Waste Management 20, 2140 - 2149.

Quartey, E. T., Tosefa, H., Danquah, K. A. B. \& Obrsalova, I. (2015) Theoretical Framework for Plastic Waste Management in Ghana through Extended Producer Responsibility:
Case of Sachet Water Waste. International Journal of Environmental Research and Public Health 12, 9907 - 9919.

Setsonfia, D. D. (2019) Ghana Concretise its innovation and Research Commercialisation Centre [Online]. http://mesti.gov.gh/ghana-concretise-innovation-research-commercialisation-centre/. [Accessed 10-01-2020 2020].

Suryana, H., Yudoko, G., Purboyo Hidayat Putro, H. \& Dirgahayani, P. (2019) Model Reverse Logistics System of Plastic Waste Recycling at Indonesesia. Journal of Physics: Conference Series 1175, 012195.

TANDOH, F. (2018) Ghanaian company turns plastic wastes into valuable products. [Online]. www.newsghana.com.gh/ghanaian-company-turns-plastic-wastes-into-valuable-products/. [Accessed August 6, 2018. 2018].

Temitope, A. K., Abayomi, O. O., Ruth, A. O. \& AdeOLA, A. P. (2015) A Pilot Recycling of Plastic Pure Water Sachets / Bottles into Composite Floor Tiles : A Case Study from Selected Dumping Site in Ogbomoso. Material Sciences \& Engineering 4, $1-5$.

Urbanek, A. K., W. Rymowicz \& Mirończuk, A. M. (2018) Degradation of plastics and plastic-degrading bacteria in cold marine habitats. Appl Microbiol Biotechnol 102, 7669 -7678.

Received 01 Oct 19; revised 15 Jan 20. 